\title{
PRAWNE I TECHNICZNE ASPEKTY GOSPODAROWANIA ODPADAMI KOMUNALNYMI
}

\section{LEGAL AND TECHNICAL ASPECTS OF MUNICIPAL WASTE MANAGEMENT}

\section{STRESZCZENIE}

$\mathrm{W}$ artykule przedstawiono podstawowe regulacje prawne oraz rozwiązania techniczne w zakresie zasad gospodarowania oraz metod przetwarzania odpadów komunalnych. Po wprowadzeniu nowej dyrektywy „odpadowej” 2008/98/WE nastąpiły zmiany w systemie ich gospodarowania, szczególnie w zakresie ograniczenia masy odpadów deponowanych na składowiskach oraz wymogów technicznych tych

Doktor nauk biologicznych, adiunkt w Katedrze Kryminalistyki i Medycyny Sądowej Wydziału Prawa i Administracji UWM w Olsztynie.

** Doktor, adiunkt w Katedrze Mechatroniki i Edukacji Techniczno-Informatycznej Wydziału Nauk Technicznych UWM w Olsztynie. 
instalacji. Następstwem tych zmian jest wzrost udziału odpadów komunalnych poddawanych recyklingowi i kompostowaniu oraz spadek masy odpadów deponowanych na składowiskach.

\section{Słowa kluczowe}

Odpady komunalne; prawny system gospodarowania; metody odzysku i unieszkodliwiania.

\section{ABSTRACT}

The article shows basic legal regulations and technical methods of municipal waste management and its processing. After the implementation of Waste Directive 2008/98/WE, changes in the waste management system occurred, especially in the scope of the limitation of waste mass disposed in landfills and technical requirements of these installations. The consequence of these changes is the increase in municipal waste recycling and composting and the decrease in waste disposed in landfills.

\section{Keywords}

Municipal waste; waste management legal system; recovery and neutralisation methods.

\section{WSTĘP}

Odpady komunalne są nieodłącznym elementem bytowania człowieka. Zgodnie z art. 3 pkt 7 ustawy z dnia 14 grudnia 2012 r. o odpadach z (u.o.o.) ${ }^{1}$ mianem odpadów komunalnych określa się odpady powstające $\mathrm{w}$ gospodarstwach domowych, z wyłączeniem pojazdów wycofanych z eksploatacji, a także odpady niezawierające odpadów niebezpiecznych, pochodzące od innych wytwórców odpadów, które ze względu na swój charakter lub skład są podobne do odpadów powstających w gospo- 
darstwach domowych. Odpady komunalne poza gospodarstwami domowymi powstają również w budynkach użyteczności publicznej czy w przemyśle spożywczym.

Masa odpadów komunalnych wzrasta wraz z liczbą mieszkańców oraz poziomem ich życia. Spośród krajów Unii Europejskiej w 2009 roku najwięcej odpadów komunalnych zostało wyprodukowanych w Niemczech na poziomie $831 \mathrm{~kg} / \mathrm{miesz-}$ kańca, a najmniej w Czechach - $316 \mathrm{~kg} /$ mieszkańca. W Polsce wielkość ta wynosiła $370 \mathrm{~kg}$ odpadów komunalnych na 1 mieszkańca, podczas gdy średnia krajów UE wynosiła 440 kg/M/rok². Odpady komunalne charakteryzują się bardzo różnorodnym składem, a mianowicie zawierają takie frakcje, jak odpadki organiczne, papier, szkło, metale, tworzywa sztuczne, a także odpady zawierające składniki niebezpieczne, np. baterie, zużyte akumulatory samochodowe, sprzęt elektryczny i elektroniczny itd. Ze względu na ich różnorodność efektywne gospodarowanie takimi odpadami jest bardzo trudne i wymaga wielu działań legislacyjnych i organizacyjnych. Gospodarkę odpadami komunalnymi reguluje ustawa o odpadach, i akty wykonawcze do tej ustawy, która była już kilkadziesiąt razy zmieniana. Zmiany te głównie były podyktowane potrzebą uporządkowania gospodarki odpadami komunalnymi w zakresie ograniczenia ich masy oraz większej efektywności metod przetwarzania tych odpadów, czyli odzysku i unieszkodliwiania.

Przedmiotem rozważań w niniejszym artykule są podstawowe regulacje prawne i rozwiązania techniczne w zakresie gospodarowania odpadami komunalnymi na tle zmian w tym systemie zainicjowanych nową dyrektywą „odpadową” 2008/98/WE.

\section{ZASADY I HIERARCHIA POSTĘPOWANIA Z ODPADAMI}

Po wejściu w życie dyrektywy Parlamentu Europejskiego i Rady 2008/98/WE z dnia 19 listopada 2008 r. w sprawie

2 K. Blumenthal, Environment and energy. Statistics in focus, Eurostat 2011, s. 2. 
odpadów, uchylającej niektóre dyrektywy ${ }^{3}$, zmieniły się zasady i hierarchia postępowania i gospodarowania odpadami. Państwa członkowskie, w tym także i Polska, były zobowiązane do wprowadzenia nowych przepisów ustawowych, wykonawczych i administracyjnych do 12 grudnia 2010 r $^{4}$. Do ogólnych zasad w ujęciu teoretycznym w zakresie gospodarki odpadami transponowane z dyrektywy odpadowej zostały:

1) zasada ochrony zdrowia i życia ludzi oraz przestrzegania wymagań ochrony środowiska,

2) zasada przestrzegania hierarchii sposobów postępowania z odpadami,

3) zasada bliskości,

4) zasada „zanieczyszczający płaci” połączona z zasadą rozszerzonej odpowiedzialności producenta,

5) zasada odpowiedzialności posiadacza za zgodne z prawem zagospodarowanie odpadów ${ }^{5}$.

W ujęciu prawnym zasady gospodarowania odpadami są podporządkowane ochronie życia i zdrowia ludzi oraz ochronie środowiska zgodnie z zasadą zrównoważonego rozwoju ${ }^{6}$. Ustawa z 2012 roku o odpadach określa środki służące ochronie środowiska, życia i zdrowia ludzi, zapobiegające i zmniejszające negatywny wpływ na środowisko oraz zdrowie ludzi, wynikający z wytwarzania odpadów i gospodarowania nimi, oraz ograniczające ogólne skutki użytkowania zasobów i poprawiające efektywność takiego użytkowania (art. 1). Istota tych środków $\mathrm{z}$ jednej strony sprowadza się do ograniczenia negatywnego oddziaływania, wynikającego z szeroko rozumianej gospodarki odpadami, czyli wytwarzania i gospodarowania nimi, jak rów-

3 Dz. Urz. UE L 312 z 22.11.2008, s. 3.

4 Zobacz więcej: J. Jerzmański, Ustawa z 14 grudnia 2012 r. - nowe zasady gospodarowania odpadami, „Przegląd Komunalny. Gospodarka Komunalna i Ochrona Środowiska” 2013, nr 1, s. 47-66.

5 M. Górski, Nowe regulacje prawne dotyczące postępowania z odpadami, $w$ tym odpadami komunalnymi, Urząd przygotowany do przejęcia obowiązków w zakresie zagospodarowania odpadów komunalnych, materiały szkoleniowe, Poznań 2013, s. 13.

6 J. Ciechanowicz-McLean, Ochrona środowiska $w$ działalności gospodarczej, Warszawa 2003, s. 91. 
nież późniejszego postępowania z miejscami unieszkodliwiania odpadów (art. 3 ust. 1 pkt 2). Z drugiej strony istota tych środków dotyczy gospodarki zasobami w zakresie ograniczenia skutków użytkowania odpadami oraz poprawienia efektywności tegoż użytkowania ${ }^{7}$. Zgodnie z art. 16 cytowanej ustawy gospodarkę odpadami należy prowadzić w sposób zapewniający ochronę życia i zdrowia ludzi oraz środowiska; w szczególności gospodarka odpadami nie może:

1) powodować zagrożenia dla wody, powietrza, gleby, roślin lub zwierząt;

2) powodować uciążliwości przez hałas lub zapach;

3) wywoływać niekorzystnych skutków dla terenów wiejskich lub miejsc o szczególnym znaczeniu, w tym kulturowym i przyrodniczym.

Z kolei hierarchia postępowania $\mathrm{z}$ odpadami obejmuje następujące działania: zapobieganie, przygotowanie do ponownego użycia, recykling, inne metody odzysku, np. odzysk energii oraz unieszkodliwianie. Schemat ten jest podstawową wytyczną dla państw członkowskich przy konstruowaniu systemów gospodarowania odpadami ${ }^{8}$. W art. 17 u.o.o. wprowadza się następującą hierarchię sposobów postępowania z odpadami:

1) zapobieganie powstawaniu odpadów;

2) przygotowywanie do ponownego użycia;

3) recykling;

4) inne procesy odzysku;

5) unieszkodliwianie.

Nowoczesne rozwiązania racjonalnej gospodarki odpadami komunalnymi muszą spełniać więc dwa podstawowe wymogi: (1) zgodności z zasadami ochrony środowiska i (2) zgodności z zasadami gospodarki materiałowej. Na system gospodarki odpadami składają się zbieranie, transport, odzysk i unieszko-

7 Z. Bukowski, Zakres nowej ustawy o odpadach, „Recykling” 2013, nr 2, s. $15-17$.

8 M. Górski, Aktualne regulacje prawne $w$ zakresie ochrony środowiska wg stanu prawnego na koniec stycznia 2009 r., Poznań 2009, s. 36. 
dliwianie odpadów ${ }^{9}$. Przedmiotem rozważań w niniejszym artykule będą głównie metody odzysku i unieszkodliwiania odpadów komunalnych.

\section{METODY ODZYSKU ODPADÓW}

Odzysk odpadów został zdefiniowany w art. 3 pkt 14 u.o.o. jako jakikolwiek proces, którego głównym celem jest to, aby odpady służyły użytecznemu zastosowaniu przez zastąpienie innych materiałów, które w przeciwnym przypadku zostałyby użyte do spełnienia danej funkcji, lub w wyniku którego odpady są przygotowywane do spełnienia takiej funkcji w danym zakładzie lub ogólnie w gospodarce. Metody odzysku zostały określone w załączniku nr 1 cytowanej ustawy. Wśród nich znajduje się recykling zdefiniowany jako odzysk, w ramach którego odpady są ponownie przetwarzane na produkty, materiały lub substancje wykorzystywane w pierwotnym celu lub innych celach. Recykling obejmuje ponowne przetwarzanie materiału organicznego (recykling organiczny), ale nie obejmuje odzysku energii i ponownego przetwarzania na materiały, które mają być wykorzystane jako paliwa lub do celów wypełniania wyrobisk. Zgodnie z prawodawstwem polskim recykling również obejmuje recykling organiczny, czyli kompostowanie. Należy tutaj zaznaczyć, iż recykling musi być poprzedzony selektywną zbiórką odpadów, np. „u źródła” lub w zakładach mechanicznego sortowania odpadów. Do grupy surowców, które mogą być odzyskane należą metale, papier, szkło, tworzywa sztuczne, a także obecnie odpadki biodegradowalne. Ponadto ze strumienia odpadów komunalnych wydziela się również odpady niebezpieczne, np. baterie, świetlówki, przeterminowane leki, środki ochrony roślin, farby, lakiery, kwasy, zużyty sprzęt elektryczny i elektroniczny, co ułatwia ich unieszkodliwianie ${ }^{10}$.

9 C. Rosik-Rulewska, Podstawy gospodarki odpadami, Warszawa 2007, s. 61 .

10 Ibidem, s. 64-65. 
Recykling polega na powtórnym przetwarzaniu materiałów zawartych $\mathrm{w}$ odpadach $\mathrm{w}$ procesie produkcyjnym $\mathrm{w}$ celu uzyskania substancji lub materiału o pierwotnym lub też o innym przeznaczeniu. Zasadniczym celem recyklingu jest maksymalizacja ponownego wykorzystania tych samych materiałów z uwzględnieniem optymalizacji nakładów na ich przetworzenie w stosunku do wartości otrzymanego wyrobu ${ }^{11}$. Wyróżniamy recykling materiałowy (mechaniczny) oraz surowcowy (chemiczny). Recykling materiałowy polega na ponownym przetwarzaniu odpadów w produkt o wartości użytkowej. W podstawowej wersji tej metody wielokrotnie recyklowane materiały są stosowane w kolejnych produktach o innym przeznaczeniu i o coraz mniejszych wymaganiach technologicznych i jakościowych. W nowoczesnym wydaniu recykling materiałowy polega nie tylko na odzysku materiału, ale także na jego uszlachetnieniu np. metodami compoundingu tak, że otrzymany produkt cechuje inna wartość użytkowa niż pierwotnie. Natomiast recykling surowcowy dotyczy głównie materiałów o złożonej budowie chemicznej, jak tworzywa sztuczne, guma, żywice itp., które nie nadają się do ponownego użycia metodami recyklingu mechanicznego, ale są cenne z punktu widzenia zawartych w nich surowców składowych. Podstawową zaletą tej metody jest możliwość przeróbki tworzyw bez uprzedniej ich segregacji, a główną metodą recyklingu chemicznego jest piroliza. To proces, w którym odpadowe tworzywa polimerowe są poddawane beztlenowej obróbce termicznej w specjalnym reaktorze, w wyniku której następuje kraking wiązań polimerowych. Po osiągnięciu odpowiednich progów temperaturowych w reaktorze następują procesy degradacji powodujące dzielenie łańcuchów polimerowych i otrzymywanie frakcji stałych, płynnych i gazowych. Produkty pirolizy mogą być poddawane ponownej polimeryzacji prowadzącej do uzyskania nowych tworzyw ${ }^{12}$.

11 A. Gralewska, Kłopoty z recyklingiem, „Przyroda Polska” 2010, nr 2, s. 8-9.

12 Linie do recyklingu, IPM maszyny do tworzyw sztucznych i gum, http:// ipmtc.com.pl/maszyny_nowe_1_g.html, stan na dzień 9.07.2013. 
Szczególnym rodzajem recyklingu jest recykling organiczny, któremu mogą być poddane głównie bioodpady zdefiniowane jako ulegające biodegradacji odpady z ogrodów i parków, odpady spożywcze i kuchenne $\mathrm{z}$ gospodarstw domowych, gastronomii, zakładów zbiorowego żywienia, jednostek handlu detalicznego, a także porównywalne odpady z zakładów produkujących lub wprowadzających do obrotu żywność (art. 3, pkt 1 u.o.o.). Obecnie recykling organiczny ma szczególne znaczenie w ograniczeniu masy odpadów ulegających biodegradacji przekazywanych na składowiska odpadów. W tym zakresie zgodnie z przepisami ustawy z dnia 13 września 1996 r. o utrzymaniu czystości i porządku w gminach ${ }^{13}$, gminy są obowiązane:

1) do dnia 16 lipca 2013 r. - do nie więcej niż 50\% wagowo całkowitej masy odpadów komunalnych ulegających biodegradacji przekazywanych do składowania,

2) do dnia 16 lipca 2020 r. - do nie więcej niż 35\% wagowo całkowitej masy odpadów komunalnych ulegających biodegradacji przekazywanych do składowania - w stosunku do masy tych odpadów wytworzonych w 1995 r. (art. 3c).

Recyklingiem organicznym jest kompostowanie polegające na rozkładzie substancji organicznej zachodzących w wyniku procesów biochemicznych. W procesie humifikacji następuje synteza złożonych związków organicznych, mających szczególną wartość nawozową. Substancje humusowe wprowadzone do gleby z kompostem powodują powiększenie jej kompleksu sorpcyjnego, a tym samym urodzajności. Proces kompostowania przebiega $\mathrm{w}$ dwóch etapach. Pierwszym etapem jest kompostowanie intensywne, w trakcie którego z odpadów organicznych jest otrzymywany kompost świeży, materiał ulega higienizacji, substancje łatwo rozkładalne zostają praktycznie rozłożone i maleje potencjalna zdolność emisji odorów. W etapie drugim dojrzewaniu, z kompostu świeżego uzyskuje się kompost dojrzały. Rozkładane są substancje trudno rozkładalne (np. ligniny), powstają natomiast stabilne struktury próchnicze, zawierające substancje odżywcze, odporne na działanie czynników 
zewnętrznych ${ }^{14}$. Wyróżnia się trzy podstawowe rodzaje kompostowania:

1) kompostowanie w pryzmach (wys. $1,5 \mathrm{~m}$ i szer. $2,0 \mathrm{~m}$ ) formowanych na otwartej przestrzeni, zadaszonych i obudowanych, przy zachowaniu odpowiednich warunków wilgotności, temperatury, napowietrzania i mieszania; dotyczy odpadów przeselekcjonowanych czyli pozbawionych części metalowych, kamieni, tworzyw sztucznych, odpadów niebezpiecznych) oraz rozdrobnionych;

2) kompostownie przewoźne - odpady mogą być przemieszczane z jednego miejsca nagromadzenia w drugie szczególnie w gminach posiadających kilka składowisk odpadów;

3) kompostowanie kontenerowe - rozpoczyna się od segregacji i wymieszania dostarczonych odpadów i napełnienia kontenerów; następnie napełnione kontenery przekazane zostają do sekcji intensywnego kompostowania, gdzie podłączone zostają do systemu na- i odpowietrzającego ${ }^{15}$.

\section{METODY UNIESZKODLIWIANIA ODPADÓW}

Zgodnie z art. 3 pkt 30 u.o.o. unieszkodliwianie odpadów to proces niebędący odzyskiem, nawet jeżeli wtórnym skutkiem takiego procesu jest odzysk substancji lub energii. Wykaz procesów unieszkodliwiania został umieszczony w załączniku nr 2 do cytowanej ustawy. Wśród procesów unieszkodliwiania najczęściej stosowanymi metodami jest termiczne przekształcanie odpadów (spalanie) i ich składowanie. Spalanie to najbardziej

14 K. Kucharczyk, W. Stępień, B. Gworek, Kompostowanie odpadów komunalnych jako metoda odzysku substancji organicznej, „Ochrona Środowiska i Zasobów Naturalnych" 2010, nr 42, s. 240-254.

15 B. Bilitewski, G. Hardtle, K. Marek, Podręcznik gospodarki odpadami. Teoria i praktyka, Warszawa 2006, s. 292-326. 
radykalna metoda unieszkodliwiania odpadów, zarówno przemysłowych, medycznych, jak i komunalnych. Spalanie odpadów odbywa się w specjalnych instalacjach do tego celu przeznaczonych, określanych mianem spalarni odpadów. W myśl art. 3 pkt 26 u.o.o. spalarnia odpadów to zakład lub jego część przeznaczone do termicznego przekształcania odpadów z odzyskiem lub bez odzysku wytwarzanej energii cieplnej, obejmujące instalacje i urządzenia służące do prowadzenia procesu termicznego przekształcania odpadów wraz z oczyszczaniem gazów odlotowych i wprowadzaniem ich do atmosfery, kontrolą, sterowaniem i monitorowaniem procesów oraz instalacjami związanymi z przyjmowaniem, wstępnym przetwarzaniem i magazynowaniem odpadów dostarczonych do termicznego przekształcania oraz instalacjami związanymi z magazynowaniem i przetwarzaniem substancji otrzymanych w wyniku spalania i oczyszczania gazów odlotowych. W świetle znowelizowanych przepisów ustawy z dnia 13 września 1996 r. o otrzymaniu czystości i porządku w gminach ${ }^{16}$ spalarnia odpadów może stanowić samodzielną instalację przetwarzania odpadów komunalnych pod warunkiem spełnienia wymogów polegających na posiadaniu mocy przerobowej pozwalającej na przetworzenie odpadów z obszaru zamieszkałego przez co najmniej 120 tys. mieszkańców oraz jeśli jej budowa i funkcjonowanie są zgodne z BAT, a także powinna być uwzględniona w wojewódzkim planie gospodarki odpadami. Ponadto budowa spalarni odpadów wymaga uzyskania pozwolenia na budowę, poprzedzonego uzyskaniem decyzji środowiskowej wynikającej z art. 46 rozporządzenia Rady Ministrów z dnia 9 listopada 2010 r. w sprawie przedsięwzięć mogących znacząco oddziaływać na środowisko (Dz. U. nr 213, poz. 1397), która może zostać poprzedzona oceną oddziaływania na środowisko ${ }^{17}$.

W związku z dużym zagrożeniem, jakie niosą ze sobą procesy spalania dla środowiska i człowieka, muszą one przebiegać

16 Tj. Dz. U. z 2012, poz. 391.

17 Zobacz więcej: D. Ostrowiecki, Rola i miejsce spalarni odpadów w systemie gospodarowania odpadami komunalnymi na tle realizacji zrównoważonego rozwoju, „Przegląd Prawa Ochrony Środowiska” 2012, nr 4, s. 31-44. 
w odpowiednich warunkach. Szczegółowe warunki przeprowadzania procesów termicznego przekształcania odpadów określa rozporządzenie Ministra Zdrowia z dnia 23 grudnia 2002 r. w sprawie dopuszczalnych sposobów i warunków unieszkodliwiania odpadów medycznych i weterynaryjnych ${ }^{18}$. Podstawowym wymogiem sformułowanym w załączniku tego aktu prawnego jest, by podczas procesu termicznego przekształcania odpadów minimalna temperatura w komorze spalania nie była niższa niż $1000^{\circ} \mathrm{C}$, a ponadto, aby prowadzony był stały pomiar temperatury $\mathrm{w}$ komorze spalania, czasu przebywania $\mathrm{w}$ niej gazów spalinowych, jak również monitoring zawartości tlenu w gazach spalinowych oraz ciśnienia tych gazów. Pozostałości po termicznym przekształceniu odpadów należy unieszkodliwić, ze szczególnym uwzględnieniem ich składu chemicznego, w tym zawartości metali ciężkich. Najczęściej popioły i żużle są gromadzone na składowiskach odpadów niebezpiecznych.

Spalanie odpadów polega na termicznym ich przekształceniu prowadzącym do ich unieszkodliwienia. Cały proces odbywa się w spalarniach, których układ technologiczny składa się z urządzeń przygotowania odpadów do spalania: separatora metali, szkła i innych niepalnych zanieczyszczeń, a także urządzenia do rozdrabniania i mieszania oraz urządzenia dozującego. Podstawą w każdej spalarni jest piec lub komora spalania, czasem również komora dopalania, oraz układ doprowadzania powietrza i odprowadzania wilgoci. Ponadto w instalacji znajdują się też układ odprowadzania stałych produktów spalania oraz układ oczyszczania i odprowadzania spalin, w tym filtrów, skruberów itp. W efekcie zastosowania termicznego przekształcenia odpadów uzyskuje się istotną redukcję masy i objętości odpadów do ok. 10\% wartości początkowej. Istnieje wiele technologii spalania odpadów:

1) instalacje z paleniskami rusztowymi - stosowane dla opadów słabo palnych i niedużej wartości opałowej;

18 Rozporządzenie Ministra Zdrowia z dnia 23 grudnia 2002 r. w sprawie dopuszczalnych sposobów i warunków unieszkodliwiania odpadów medycznych i weterynaryjnych, Dz. U. z 2003 r., nr 8, poz. 104. 
2) piece obrotowe - stosowane dla różnych rodzajów odpadów, metoda ta zapewnia dużą elastyczność w zakresie unieszkodliwiania tych odpadów;

3) instalacje do spalania w warstwach fluidalnych - mają szerokie zastosowanie $\mathrm{w}$ krajach UE do unieszkodliwiania odpadów komunalnych;

4) układy $z$ wykorzystaniem procesu quasi-pirolizy obok pirolizy zachodzi proces zgazowania produktów powstających przy spalaniu, wysoka temperatura $1200-1400^{\circ} \mathrm{C}$ zapewnia uzyskanie wysokiego stopnia konwersji składników organicznych zawartych w odpadach $^{19}$.

Kolejną metodą zagospodarowania odpadów jest ich gromadzenie na składowiskach odpadów, których nie wykorzystano gospodarczo lub nie unieszkodliwiono w inny sposób. Składowisko odpadów to obiekt budowlany przeznaczony do składowania odpadów (art. 3 pkt 26 u.o.o.). Wyróżniamy składowiska odpadów niebezpiecznych, obojętnych oraz składowiska odpadów innych niż niebezpieczne i obojętne (art. 103 u.o.o.). Odpady przed umieszczeniem na składowisku odpadów poddaje się procesowi przekształcenia fizycznego, chemicznego, termicznego lub biologicznego, włącznie z segregacją, w celu ograniczenia zagrożenia dla życia i zdrowia ludzi lub dla środowiska oraz ograniczenia ilości lub objętości składowanych odpadów, a także ułatwienia postępowania z nimi lub prowadzenia odzysku (art. 105 u.o.o.). Powyższy proces polega przede wszystkim na różnych formach składowania odpadów, ich przekształcaniu termicznym, czy wreszcie innych procesach fizycznych, biologicznych i chemicznych ${ }^{20}$. W tym celu stosuje się mechaniczo-biologiczne techniki przetwarzania odpadów. Celem procesów mechanicznych w tej technice jest oddzielenie substancji nienadających się do przetwarzania biologicznego, związków zakłócających dalszy proces, substancji szkodliwych

19 C. Rosik-Dulewska, op. cit., s. 194-201.

20 G. Dobrowolski, Rozwój ustawodawstwa dotyczacego odpadów innych niż komunalne w Polsce, „Przegląd Prawa Ochrony Środowiska” 2013, nr 3, s. 9-28. 
oraz udoskonalenie rozkładu biologicznego pozostałych odpadów poprzez większą dostępność i utrzymanie jednorodności. Procesy biologiczne powodują rozkład substancji organicznych poprzez zastosowanie procesów tlenowych (intensywne kompostowanie) lub procesów beztlenowych (fermentowanie). Proces przygotowania mechanicznego następuje poprzez przesiewanie, frakcjonowanie powietrzne, oddzielenie materiałów stałych, wychwytywanie materiałów metalowych, z wykorzystaniem separatorów magnetycznych, oraz separację z wykorzystaniem prądów wirowych. W związku z czym konieczne jest odbieranie powietrza odlotowego z każdego urządzenia i kierowanie do urządzeń oczyszczających. Mechaniczno-biologiczne przetwarzanie odpadów prowadzi do redukcji cząstek biodegradowalnych, objętości, zawartości wody, potencjału gazotwórczego, aktywności oddechowej odpadów, jak i do udoskonalenia ługowania i osiadania odpadów ${ }^{21}$.

Funkcjonowanie składowiska odpadów obejmuje fazy przygotowania do budowy, budowy oraz prowadzenie składowiska odpadów; są one wyodrębnione jako::

1) faza przedeksploatacyjna - okres poprzedzający uzyskanie pierwszej ostatecznej decyzji zatwierdzającej instrukcję prowadzenia składowiska odpadów;

2) faza eksploatacyjna - okres od dnia uzyskania pierwszej ostatecznej decyzji zatwierdzającej instrukcję prowadzenia składowiska odpadów do dnia zakończenia rekultywacji składowiska odpadów;

3) faza poeksploatacyjna - okres 30 lat liczony od dnia zakończenia rekultywacji składowiska odpadów.

Dzień zakończenia rekultywacji składowiska odpadów jest równocześnie dniem zamknięcia tego składowiska (art. 123 u.o.o.).

Lokalizacja i budowa składowisk odpadów podlega przepisom inwestycyjnym, tzn. wymaga uzyskania decyzji o warunkach zabudowy i zagospodarowania terenu zgodnie $\mathrm{z}$ ustaleniami miejscowego planu zagospodarowania przestrzennego

21 G. Siemiątkowski (red.), Kompostowanie i mechaniczno-biologiczne przetwarzanie odpadów, Opole 2011, s. 36-42. 
oraz uzyskania pozwolenia na budowę, a także na użytkowanie obiektu. Ponadto wymagane jest przeprowadzenie procedury oceny oddziaływania na środowisko. Uwarunkowania lokalizacyjne i wymagania techniczne dotyczące warunków składowania odpadów określa przede wszystkim rozporządzenie Ministra Środowiska z 30 kwietnia 2013 r. w sprawie składowisk odpadów ${ }^{22}$. W celu ochrony wód podziemnych i powierzchniowych określono miejsca objęte zakazem lokalizowania składowisk, do których należą:

1) obszary ochronne zbiorników wód podziemnych;

2) obszary otulin parków narodowych i rezerwatów przyrody;

3) obszary lasów ochronnych;

4) doliny rzek, w pobliżu zbiorników wód śródlądowych, na terenach źródliskowych, bagiennych i podmokłych, w obszarach mis jeziornych i w strefach krawędziowych, na obszarach narażonych na niebezpieczeństwo powodzi, o których mowa w art. 88d ust. 2 z 18 lipca 2001 r. - Prawo wodne (Dz. U. z 2012 r. poz. 145, z późn.zm.);

5) strefy osuwisk i zapadlisk terenu, w tym powstałe w wyniku zjawisk krasowych oraz zagrożone lawinami;

6) tereny o nachyleniu powyżej $10^{\circ}$;

7) tereny zaangażowane glacitektonicznie lub tektonicznie, poprzecinane uskokami, spękane lub uszczelinowacone;

8) tereny wychodni skał zwięzłych porowatych, skrasowiałych i skawernowanych;

9) gleby klas bonitacji I i II;

10) tereny, na których mogą wystąpić deformacje ich powierzchni na skutek szkód spowodowanych ruchem zakładu górniczego;

11) obszary ochrony uzdrowiskowej;

12) obszary górnicze utworzone dla kopalin leczniczych;

13) obszary określone na podstawie odrębnych przepisów. 
Minimalna odległość składowiska odpadów niebezpiecznych lub składowiska odpadów innych niż niebezpieczne i obojętne od budynków mieszkalnych, budynków zamieszkania zbiorowego i budynków użyteczności publicznej, w rozumieniu przepisów prawa budowlanego, mierzona od krawędzi kwatery składowiska odpadów, jest ustalana zgodnie z raportem o oddziaływaniu składowiska odpadów na środowisko.

Natomiast do wymogów technicznych składowisk odpadów należą:

- systemy zabezpieczenia wód gruntowych, powierzchniowych i podziemnych przed wpływem odpadów

- systemy ujmowania i oczyszczania odcieków,

- systemy ujmowania i zagospodarowania biogazu,

- sprzęt technologiczny do formowania i zagęszczania odpadów,

- zaplecze techniczno-socjalne składowiska,

- system stałego monitoringu wpływu składowiska na środowisko,

- system zabiegów rekultywacyjnych ${ }^{23}$.

W świetle przepisów zawartych w rozporządzeniu z 2013 roku, w celu ochrony wód podziemnych i powierzchniowych oraz gleby należy zastosować układ bariery geologicznej i wykładziny dennej w fazie czynnej eksploatacji składowiska, a po jego zamknięciu układu bariery geologicznej i okładziny powierzchniowej. Na dnie składowiska powinna być tworzona nieprzepuszczalna bariera pomiędzy odpadami zgromadzonymi na składowisku a środowiskiem naturalnym. Minimalna miąższość naturalnej bariery geologicznej dla składowiska odpadów niebezpiecznych nie może być mniejsza niż $5 \mathrm{~m}$, natomiast dla składowisk odpadów niebezpiecznych i obojętnych oraz składowisk odpadów obojętnych nie mniejsza niż $1 \mathrm{~m}$. Wymagane jest przy tym, aby najwyższy piezometryczny poziom wód podziemnych znajdował się co najmniej metr poniżej poziomu dna składowiska. Jeżeli naturalna bariera geologiczna nie jest wystarczająco szczelna i nie zapewnia dostatecznej izolacji, wówczas należy stosować barierę sztuczną o minimalnej miąższości

23 C. Rosik-Dulewska, op. cit., s. 70. 
0,5 m, zapewniającą przepuszczalność nie większą niż określona bariera naturalna, którą wykonuje się w taki sposób, by procesy osiadania na składowisku odpadów nie mogły spowodować jej zniszczenia. Uzupełnieniem naturalnej lub sztucznej bariery geologicznej jest izolacja syntetyczna, zaprojektowana w sposób uwzględniający skład chemiczny odpadów i warunki geotechniczne składowania; przy czym izolacja syntetyczna nie może stanowić elementu stabilizacji zboczy składowiska (§4). Obowiązkowe jest ponadto wyposażanie składowiska odpadów niebezpiecznych w system drenażu wód odciekowych zaprojektowany w sposób zapewniający jego niezawodne funkcjonowanie, zarówno w trakcie eksploatacji składowiska oraz przez co najmniej trzydzieści lat od dnia jego zamknięcia (§5). Ponadto w system drenażu należy wyposażyć także zbocza składowiska odpadów, co umożliwia spływ wód odciekowych do głównego systemu drenażu, a także zewnętrzny system rowów drenażowych wokół składowiska odpadów uniemożliwiający dopływ wód powierzchniowych i podziemnych do składowiska odpadów (§7). Istotnym elementem składowiska, na którym przewiduje się składowanie odpadów ulegających biodegradacji, jest instalacja do odprowadzania gazu składowiskowego, który oczyszcza się i wykorzystuje do celów energetycznych, a jeżeli jest to niemożliwe - spala w pochodni (§8). Podkreślenia wymaga ponadto fakt, aby sposób, lokalizacji składowiska odpadów zapewniał jego niedostępność dla osób nieuprawnionych (§9). Składowisko odpadów otacza się pasem zieleni izolacyjnej złożonym z drzew i krzewów o minimalnej szerokości 10 m, w celu ograniczenia do minimum niedogodności i zagrożeń powstających na składowisku odpadów w wyniku emisji odorów i pyłów, roznoszenia odpadów przez wiatr, hałasu i ruchu drogowego, oddziaływania zwierząt, tworzenia się aerozoli oraz pożarów (§10). Składowisko odpadów powinno być także wyposażone w wagę samochodową i brodzik dezynfekcyjny. Eksploatacja składowiska odpadów powinna zapewniać ograniczenie powierzchni składowanych odpadów eksponowanych na oddziaływanie warunków atmosferycznych, przeciwdziałanie rozwiewaniu odpadów, gromadzenie wód odciekowych i poddawanie 3/2014 ich oczyszczaniu w stopniu umożliwiającym ich przyjęcie na 
oczyszczalnię ścieków lub odprowadzenie do wód lub do ziemi oraz stateczność geotechniczną składowanych odpadów (§13). Wreszcie zaznaczenia wymaga, iż po przeprowadzeniu procesu likwidacji i zamknięcia składowiska odpadów, konieczna jest jego rekultywacja, zapewniająca wyeliminowanie jego szkodliwego wpływu na wody powierzchniowe i podziemne oraz powietrze, a także integrująca obszar byłego składowiska odpadów ze środowiskiem w sposób umożliwiający pełną obserwację jego wpływu na środowisko. W tym celu stosuje się uszczelnienie powierzchni składającej się z warstwy ekranującej, drenażowej oraz wierzchniej warstwy ziemi o miąższości nie mniejszej niż $1 \mathrm{~m}, \mathrm{z}$ żyzną warstwą gleby pozwalającą na wegetację roślin. Rekultywacja składowiska polega więc na przykryciu odpadów warstwą gleby i zasianiu trawy lub zasadzeniu drzew np. wierzby energetycznej.

Analizując ogólną tendencję struktury zagospodarowania odpadów komunalnych w krajach UE, należy stwierdzić, iż w latach 1995-2009 nastąpił spadek masy odpadów deponowanych na składowiskach o $32 \%$, a nastąpił wzrost masy odpadów poddanych recyklingowi o 172\%, w tym organicznemu (kompostowaniu) o 239\%. W 2009 roku, do krajów o największym stopniu recyklingu należały Niemcy (48\%) oraz Belgia i Szwecja (36\%), podczas gdy największy udział odpadów był kompostowany w Austrii (40\%) i Holandii (28\%). Polska na tle innych krajów UE w 2009 roku była na średnim poziomie, a mianowicie udział odpadów deponowanych na składowiskach wynosił 76\%, poddanych recyklingowi 15\% i kompostowaniu 8\%24. W 2012 roku proporcje te znacznie się zmieniły, kiedy największa masa odpadów komunalnych była poddawana recyklingowi $(51,66 \%)$, a na składowiska było kierowanych 39,42\% tych odpadów ${ }^{25}$.

24 K. Blumenthal, op. cit., s. 5.

25 GUS, Ochrona środowiska. Informacje i opracowania statystyczne. Warszawa 2013, s. 345. 


\section{ZAKOŃCZENIE}

Gospodarowanie odpadami komunalnymi z uwagi na ich dużą różnorodność i uciążliwość dla środowiska jest niezwykle trudne zarówno pod względem legislacyjnym, jak i technicznym. Po wejściu w życie nowej dyrektywy 2008/98/WE nastąpiły istotne zmiany $\mathrm{w}$ prawodawstwie polskim $\mathrm{w}$ zakresie gospodarowania tymi odpadami. Zmiany te dotyczyły nie tylko zasad i hierarchii postępowania z odpadami, ale także zasad ich przetwarzania; szczególnie dotyczyło to składowania odpadów. Poza wymogiem ograniczenia masy odpadów ulegających biodegradacji kierowanych na składowiska odpadów rozszerzono katalog wymogów technicznych składowisk odpadów. Należy tutaj zaznaczyć, iż nie tylko składowiska odpadów, ale także inne technologie odzysku i unieszkodliwiania odpadów bez względu na to, czy stanowią element RIPOK-ów, czy są oddzielnymi instalacjami, muszą spełniać wymagania BAT, czyli zapewnić kompleksową ochronę środowiska polegającą na zminimalizowaniu ich negatywnego wpływu na wszystkie elementy środowiska takie jak powietrze, gleba oraz wody powierzchniowe i podziemne. Następstwem działań legislacyjnych w UE, w tym również i w Polsce, jest istotna zmiana w strukturze zagospodarowania odpadów komunalnych polegająca na wzroście masy odpadów poddanych recyklingowi i kompostowaniu, a spadku masy odpadów deponowanych na składowiskach.

\section{BIBLIOGRAFIA}

Bilitewski B., Hardtle G.,. Marek K, Podręcznik gospodarki odpadami. Teoria i praktyka, Warszawa 2006.

Blumenthal K., Environment and energy. Statistics in focus, Eurostat 2011.

Bukowski Z., Zakres nowej ustawy o odpadach, „Recykling” 2013, nr 2. Ciechanowicz-McLean J., Ochrona środowiska $w$ dziatalności gospodarczej, Warszawa 2003. 
Dobrowolski G., Rozwój ustawodawstwa dotyczq̨cego odpadów innych niz komunalne w Polsce, „Przegląd Prawa Ochrony Środowiska” 2013, nr 3.

Górski M., Nowe regulacje prawne dotyczace postępowania z odpadami, $w$ tym odpadami komunalnymi, Poznań 2013.

Górski M., Aktualne regulacje prawne w zakresie ochrony środowiska wg stanu prawnego na koniec stycznia 2009 r. Poznań 2009.

GUS, Ochrona środowiska. Informacje i opracowania statystyczne, Warszawa 2013.

Jerzmański J., Ustawa z 14 grudnia 2012 r. - nowe zasady gospodarowania odpadami, „Przegląd Komunalny. Gospodarka Komunalna i Ochrona Środowiska" 2013, nr 1.

Kucharczyk K., Stępień W., Gworek B., Kompostowanie odpadów komunalnych jako metoda odzysku substancji organicznej, „Ochrona Środowiska i Zasobów Naturalnych" 2010, nr 42.

Ostrowiecki D., Rola i miejsce spalarni odpadów w systemie gospodarowania odpadami komunalnymi na tle realizacji zrównoważonego rozwoju, „Przegląd Prawa Ochrony Środowiska” 2012, nr 4.

Rosik-Rulewska C., Podstawy gospodarki odpadami, Warszawa 2007.

Siemiątkowski G. (red.), Kompostowanie i mechaniczno-biologiczne przetwarzanie odpadów, Opole 2011.

Kontakt e-mail:

elzbieta.zebek@uwm.edu.pl

marek.raczkowski@uwm.edu.pl 